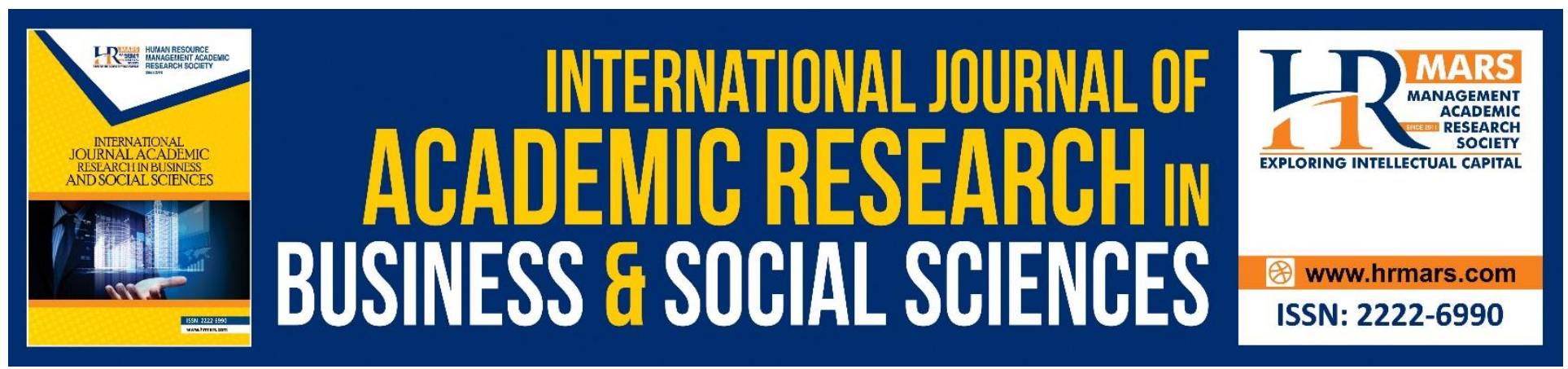

\title{
Empowering ESL Teachers' Professional Development through Digital Literacy
}

Gunavathy a/p Suppiah, Ong Chuin Yin, Moomala Othman, Lilliati Ismail, Dalia Aralas

To Link this Article: http://dx.doi.org/10.6007/IJARBSS/v8-i12/5002

DOI: $10.6007 /$ IJARBSS/v8-i12/5002

Received: 23 Oct 2018, Revised: 17 Nov 2018, Accepted: 03 Dec 2018

Published Online: 18 Dec 2018

In-Text Citation: (Suppiah, Yin, Othman, Ismail, \& Aralas, 2018)

To Cite this Article: Suppiah, G. a/p, Yin, O. C., Othman, M., Ismail, L., \& Aralas, D. (2018). Empowering ESL

Teachers' Professional Development through Digital Literacy. International Journal of Academic Research in Business and Social Sciences, 8(12), 146-154.

\section{Copyright: (C) 2018 The Author(s)}

Published by Human Resource Management Academic Research Society (www.hrmars.com)

This article is published under the Creative Commons Attribution (CC BY 4.0) license. Anyone may reproduce, distribute, translate and create derivative works of this article (for both commercial and non-commercial purposes), subject to full attribution to the original publication and authors. The full terms of this license may be seen

at: http://creativecommons.org/licences/by/4.0/legalcode

Vol. 8, No. 12, 2018, Pg. 146 - 154

http://hrmars.com/index.php/pages/detail/IJARBSS

JOURNAL HOMEPAGE

Full Terms \& Conditions of access and use can be found at http://hrmars.com/index.php/pages/detail/publication-ethics 


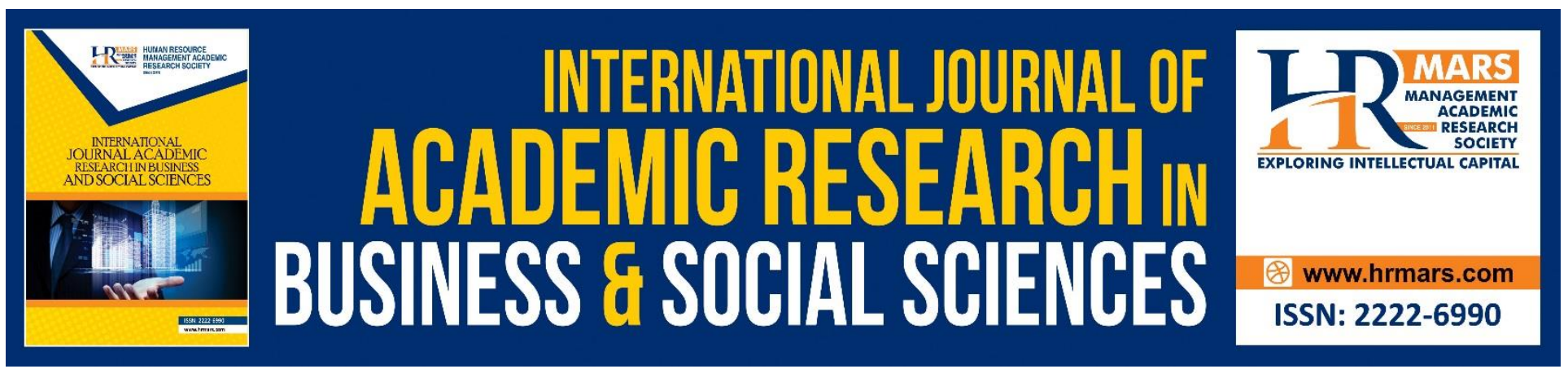

\title{
Empowering ESL Teachers' Professional Development through Digital Literacy
}

\author{
Gunavathy a/p Suppiah, Ong Chuin Yin, Moomala Othman, Lilliati \\ Ismail, Dalia Aralas
}

Faculty of Educational Studies, Universiti Putra Malaysia, 43400 UPM Serdang, Selangor Darul Ehsan, Malaysia

\begin{abstract}
With todays technology, teachers need to have digital literacy. It is a key requirement for teachers' professional growth in order to be functional in today's teaching profession. Thus it is important for teachers to have a digital mindset. Teachers need to be techno savvy and use available online interactive platforms in sharing their teaching practice. Advancement in technology provides opportunities for the learning processes as one is able to access various forms of information as well as share one's ideas through the use of multi-modal communication style. This paper aims to overlook at ICT as not only as a teaching tool but as a platform to exchange knowledge among teachers or instructors. Teachers can then creatively produce and contribute resources to be shared with others online. Raising awareness among teachers of the importance of digital literacy, will foster teachers' continuous and lifelong professional development.
\end{abstract}

Keywords: Digital literacy, technology, professional development, teacher awareness, education

\section{Introduction}

Engaging with new technologies for communication, work and leisure has become parts of our daily live in today's digital age. For years now, technology has been playing a vital role in education. "The 21st Century is here and more literate citizen is expected to use technology to access, analyze and communicate information by knowing how to manage electronic information from an ever-widening range of resources and in a wide variety of formats" (Shapley, Sheehan, Maloney, \& CaranikasWalker, 2010 as cited in Raob, Al-Oshaibat, \& Ong, 2012). Since, technology is now integrated in education at a very high standard; pressure is placed on teachers to be able to be digital literate. However, question arises as teachers are not as prepared as they should be in integrating technology as part of their professional development apart from using technology in their lessons only. Teachers should be aware of many platforms available to learn and share teaching resources from the internet. It is what we can say as, sharing knowledge among teachers despite geographical dispense to enhance their teaching and learning experience. 
Digital literacy is considered as a key requirement for the teachers to be functional in today's teaching profession. Teachers' digital literacy must incorporate the ability to use technologies effectively in their teaching practices in order to ensure that students are empowered with adequate $21^{\text {st }}$ century skills. Also, teachers need to be digitally literate so that they can engage in strong communication and collaboration, interact with technologies in a meaningful way, and discover better uses for technological resources. In addition, teachers must take initiatives to share their knowledge and teaching resources in International arena to be a step of developing life-long learning and develop in their profession. It is anticipated that teachers nowadays are aware of the use of technologies, however, they do not entirely perceive and understand what and how their digital mindsets could affect their professional growth.

Teachers demonstrate their digital literacy in planning their lessons creatively and provide a fun learning experience for their students. However, it cannot be denied that when teachers work in isolation, their level of creativity in using technology for curriculum planning can be static at one point and they would not progress any longer.

These teachers are the target group of this study, in which we want to help them to realize that they have to constantly be active in platforms available to interact with teachers from all over the world in enhancing their professional development as well as their creativity. Therefore, this paper aims to create engagement between teachers worldwide in sharing their teaching resources and share knowledge on teaching processes. Teachers could then experiment and utilize their digital literacy to enhance their teaching skill and develop their professionalism. they will also benefit by developing their self-efficacy with the opportunity to reflect on their creativity of using technology in engaging the students into the lesson.

\section{What is Digital Literacy?}

Literacy, as we all know, is predominantly defined as the skill of reading and writing. However, for the past years, since technology has taken over the world, literacy is evaluated based on perceiving information in any form. Erstad (2007) highlighted "skills, knowledge and attitudes in using digital media to be able to master challenges in the learning society". Learning society refers to the learners whose culture of learning new knowledge through various ways especially through social media and other online services. Erstad (2007), also disclosed that, "digital literacy can be computed from basic ICT skills, for instance, to comprehend available resources and make use of documents available in writing, prior to developing higher computer abilities which makes inventive as well as using medias and tools in digital technology significantly." (UNESCO, 2003 as cited in Karpati, 2011), defined literacy as the ability to classify, recognize, understand, produce, correspond and compute, using printed and written materials allied with varying contexts.

Additionally, there are other definitions of digital literacy too, "Digital literacy refers to the more subtle and positioned practices connected with being able to create, understand and communicate meaning and knowledge in a world which these processes are progressively being mediated through 
digital technologies" (Futurelab, 2010 as cited in Digital Literacy, 2015). Digital literacy is not only the ability to handle computers, but it also includes the use and presentations of digital media, information retrieving and processing, creation and sharing of knowledge in social networks, and utilizing of creative applications such as digital photography, video and audio editing (Karpati, 2011; The Royal Society, 2012).

\section{Teacher Professional Development}

Professional development is crucial in every job scope to ensure enhancement of the individual's professionalism. "The phrase professional development states that teachers are deficient and in need of developing and directing" (Webster-Wright, 2009). Teaching profession demands high need for teachers to constantly develop their skills and enhance their students' learning experience with more advanced skills. Teachers are seen successful only when they are able to learn new skills and use various techniques to engage learners to lesson. This stance is supported by Avalos (2011 as cited in Postholm, 2012) in which it was stated that 'teacher professional development means teachers' continuously learn and enhance their skills, analyze their learning styles and demonstrate their knowledge in practice to support pupils' learning.

"Teacher development is the professional growth a teacher obtains as a consequence of gained experience and evaluating his or her teaching systematically" (Glatthorn, 1995). Teachers can evaluate the effectiveness of their teaching experience based on the perceptions from their students and teachers themselves. With the ability to use Internet platforms, teachers can even engage in the platforms with all the other teachers where collaborative evaluation can take place. Ganser (2000) stated, "professional development could be nurtured in formal experiences such as attending workshops or professional meetings, mentoring, etc; or informal experiences, such as reading professional publications, watching television documentaries related to any academic disciplines, etc".

\section{Enhancing Teachers' Professional Development through Digital Literacy}

"Twenty-first-century teachers are required to develop the skills that will enable them to exploit the use of the computer as a teaching resource to develop students' learning process and to train students to compete in high technology society, in which standard of living, attitudes, and expertise are challenged daily" (Ministerial Advisory Council on the Quality of Teaching, 1995 as cited in Raob et al., 2012). Although printed teaching materials are always handy in bookstores, teachers nowadays are expected to produce their own teaching materials or resources through the usage of technology. This is the best way to attract the learners' interest towards lesson as well as getting teachers to be creative in producing their teacher resources. However, usage of technology does not limit a teacher's ability to use it only in class but outside class too, as part of their personal growth and professional growth. Teachers with digital literacy would know the platforms available for them to share their knowledge with other teachers. Collaborative learning does not only necessarily apply to the students but for teachers too, as part of enhancing their professionalism. 
In education, "there are many advantages that can be gained for both teachers and students when teachers apply ICT in their teaching, hence, it is very important to reform conventional teaching and learning process to adapt with the emergence of the new digital literacy", as stated by Bala, Mansor, Stapa, \& Zakaria (2012). Using ICT in their lessons is part of teachers' professional development. "One of the ways that can be used to show how ICT relates with teacher professional development is the existence of online communities that provide functions for teachers to interact with each other for knowledge sharing" (Bala et al., 2012). However, apart from using their technology knowledge only for their lesson, teachers' can actually develop their professionalism through sharing knowledge among teacher communities. "Moreover, support given by them to each other in online community may contribute to teacher space to reflect on their pedagogical approach" (Bala et al., 2012). Online community can be a platform for teachers to reflect on their teaching resources and materials used in lessons.

\section{Research Evidence on Usage of Technologies to Enhance Teacher Professional Development}

In recent years, teachers have discovered ways in which technologies can be adapted to support their professional development and break down the barriers of time and space. With the aid of technology, materials and resources from one context can be shared with teachers in another place and time.

Several studies suggest that teachers engage with online technologies to share knowledge and resources on their teaching practices (Hur \& Brush, 2009; Manca \& Ranieri, 2014; Zandi, Thang, \& Krish, 2014).

According to Hur \& Brush (2009), teachers participation in the digital platforms can potentially improve teachers' creativity by exploring the never lacking new ideas with counterparts around the globe. Techers participation in the virtual communities via the internet proved to support teachers by making it easier to obtain comments or suggestions that fit their realistic classrooms situations. Hur \& Brush (2009) further revealed that teachers contributed their ideas in the virtual communities by explaining what they had been carried out in their own classrooms and the reasons why this or that way may work wonders. Hence it also helps saving teachers' precious time by avoiding trials and errors in their practices when they can easily try out fellow teachers' contributed ideas. In addition, a diverse range of teaching ideas were posted via internet whenever a teacher inquired for suggestions about teaching and thus broaden their perspectives, and creative ideas may be continually generated.

In the study by Manca \& Ranieri (2014), they indicated that the five group founders of Facebook groups for teachers founded the groups to improve the process of sharing information and resources, as well as to provide professional support to its group members. Facebook is user-friendly, it provides teachers with a digital platform where chances to meet worldwide counterparts is as easy as a fingerclick, and a diverse range of feedbacks can be received instantly. This thus leads to positive and collaborative professional activities facilitated by Facebook. 
The use of blog promotes collaborative interactions within EFL teachers (Zandi et al., 2014). Blog, as one of the digital interactive platform via the internet, emerged as a digital space for the teachers to carry out discussions anytime anywhere. In their study, Zandi et al. (2014) discovered that blog can be used as a means of teaching writing skills. Teachers contributed ideas through blogging on how to integrate technologies into the teaching of writing and hence engaged fellow teachers' professional development when the teacher participants actively involved in blogging. Also, the EFL teachers believed that the use of blog in teaching writing increased the level of students' engagement as blogging allowed the students to interact effectively with their peers and boost their writing ability.

While most research focus on the use of technologies as an online interactive platform to share knowledge and resources, some studies focus on the reasons for teacher participation in teacher professional development via the internet. Notably, the study conducted by Hur \& Brush (2009) investigated the causes of teachers' involvement in virtual communities among fellow teachers. In their study, twenty-three teachers were interviewed and more than two thousand postings were analyzed. The findings of the study can be summarized as follows:

- Teachers participated in the virtual population in sharing both positive as well as negative emotions associated with teaching. They received emotional support in addition to various kind of solutions to issues related to teaching through sharing emotions in the communities.

- Virtual communities provided spaces where teachers could securely address issues and discuss along with other teachers who have diverse range of experiences. Teachers have the anxiety of being labeled as incapable in case they voiced their difficulty in teaching with colleagues at work.

- Virtually meeting teachers who share common interests made teachers feel less isolated. There was no time to talk to colleagues at work, hence teachers participated in virtual communities as a connecting source with fellow teachers who may understand issues related in teaching.

- Reviewing postings in the virtual communities facilitated teachers in producing new lessons activities creatively while at the same time they can monitor their own teaching style.

- Teachers felt deepening judgement of camaraderie when they participated in the virtual communities of fellow teachers.

\section{Research Evidence on Teachers' Digital Mindsets Influence Teaching with Technologies}

Although using technologies in enhancing teachers' professional development has been acknowledged, teachers do not entirely perceive and understand what and how their digital mindsets could affect their professional growth.

The study by Tour (2015) explored how the teachers' digital mindsets affected the way in which teachers integrated technologies into their language teaching practices.

Teachers' digital mindsets that are framed within perceiving technologies as a means of supporting and improving teachers' professionalism would usually use technologies as a tool to facilitate students' language acquisition. One of the teacher participants, Teacher $L$ integrated technologies 
into her language teaching and used them as digital version of grammar-drilling exercises. In addition, she employed videos as a substitute for traditional methods used to enhance students' listening skills and vocabulary. Also, her students are encouraged to use word processor Microsoft Word, but in not much difference ways of how the students use their paper notebooks. She strongly believed that technologies can be implemented as a tool to support her language teaching in developing her students' language skills. "Teachers' perceiving of technologies in supporting their teaching can hinder the development of their students' literacy competences" (Tour, 2015).

In contrast, teachers' comprehensive, elaborated and creative assumptions about the possibilities of technologies created plenty of opportunities for students to engage into digital literacy. Contrary to Teacher L, Teacher J participated in professional discussions, connected and collaborated with worldwide counterparts, and at the same time she was both a producer and consumer of resources in the digital spaces. She designed an ICT-supported game-based language learning activities that were made available for her students via the internet. By experimenting endless possibilities with technologies, she created a diverse range of language learning activities which facilitated her students' digital literacy practices that were collaborative and interactive.

\section{Conclusion}

Our review of research and literature has revealed that enhancing ESL teacher professional development through digital literacy is the trends in this digital age. Teachers should engage in online technologies to learn and share knowledge and resources in the easily accessible digital platforms on their own time and at their own pace. Notably, this requires individual teachers' awareness because, as this paper explains, empowering teachers' professional development through digital literacy could be constrained by teachers' digital mindsets.

Technology usage in education is vital as students nowadays only get attracted to the lessons if there is exciting features added. Although, teachers are improvising themselves in using technology to get engaged with the students on and out of the class, they still lack in awareness on the platforms available for them to share resources. Collaborative learning among teachers worldwide would definitely benefit them to be creative in producing their teaching materials. Teachers can also be creative as they can reflect on their teaching resources and its' function. Digital literacy in this study is seen as an informal professional development, where teachers get to improve themselves with their own effort using various sources available in the Internet.

According to Jenkins, Purushotma, Weigel, Clinton, \& Robinson (2009 as cited in Trust, Krutka, \& Carpenter, 2016), "online spaces is described specifically as ideal learning environments because they offer peer support learning among participants who connect based on their personal interest and individual expectations." The study on past researches on technology use for teachers' professional development has clearly indicated that teachers do benefit widely through collaborating with other teachers. Eventually it creates a positive attitude to the teachers to keep enhancing themselves and be creative in using the digital tools to prepare their lessons as well as use it for their personal growth. With this paper, we believe teachers will get a chance to open their mind to keep learning on the various usage of technology, not in isolation but together with other teachers worldwide. This will 
provide an opportunity for teachers who are still lacking in ICT skill to get tips in enhancing themselves to indulge more on the internet as a source for them to communicate with teachers out there. There are also teachers who are always eager in sharing their teaching resources as well as sharing their experience in teaching particular lessons, and these online platforms can serve as a tool to bring them all together in one arena. In conclusion, teachers are expected to shine through their career to enable them to be competitive in this profession. They should not stop learning and be aware that the Internet has many ways for them to upgrade themselves. Teachers no longer have to work in isolation, whereas they can share their thoughts and ideas in International arena and build an image for them in the professional growth.

\section{References}

Bala, S. S., Wan Mansor, W. F. A., Stapa, A., \& Zakaria, M. H. (2012). Digital Portfolio and Professional Development of Language Teachers. Procedia - Social and Behavioral Sciences, 66(2012), 176 186.

Digital Literacy. (2015). Retrieved from https:/education.gov.mt/en/elearning/Documents/ Green\%20Paper\%20Digital\%20Literacy\%20v6.pdf

Erstad, O. (2007). Conceiving Digital Literacies in Schools - Norwegian Experiences. Proceedings of the 3rd International workshop on Digital Literacy, 1-10.

Ganser, T. (2000). An ambitious vision of professional development for teachers. NASSP BULLETIN, 84(618), 6-12.

Glatthorn, A. (1995). Teacher Development. In L. Anderson (Ed.), International encyclopaedia of teaching and teacher education (p. 41). London, Pergamon Press.

Hur, J. W., \& Brush, T. A. (2009). Teacher participation in online communities: Why do teachers want to participate in self-generated online communities of K-12 teachers? Journal of Research on Technology in Education, 41 (3), 279-303.

Karpati, A. (2011). Digital Literacy in Education. UNESCO Institute for Information Technologies in Education.

Manca, Stefania \& Ranieri, Maria. (2014). Teachers' professional development in online social networking sites. EdMedia, Tampere, Finland.

Postholm, M. B. (2012). Teachers' professional development: a theoretical review. Educational Research, 54(4), 405-429. doi: 10.1080/00131881.2012.734725

Raob, I., Al-Oshaibat, H., \& Ong, S. L. (2012). A factor analysis of teacher competency in technology. New Horizons in Education, 60(1), 13-22.

The Royal Society. (2012). Shutdown or restart? The way forward for computing in UK schools. Retrieved from http: //royalsociety.org/education/policy/computing-in-schools/report/

Tour, E. (2015). Digital mindsets: Teachers' technology use in personal life and teaching. Language Learning \&Technology, 19(3), 124-139.

Trust, T., Krutka, D. G., \& Carpenter, J. P. (2016). "Together we are better": Professional learning networks for teachers. Computers \& Education, 102(2016), 15-34.

Webster-Wright, A. (2009). Reframing Professional Development through Understanding Authentic Professional Learning. Review of Educational Research, 79(2), 702-739. doi:10.3102/0034654308330970 
INTERNATIONAL JOURNAL OF ACADEMIC RESEARCH IN BUSINESS AND SOCIAL SCIENCES

Vol. 8, No. 12, Dec, 2018, E-ISSN: 2222-6990 @ 2018 HRMARS

Zandi, P., Thang, S.M., \& Krish, P. (2014). Teacher professional development through blogging: Some preliminary findings. Procedia - Social and Behavioral Sciences, 118(2014), 530 - 536. 